Vol. 8(2), pp. 042-051, February, 2018

ISSN: 2276-7770; ICV: 6.15

Copyright $\odot 2018$, the copyright of this article is retained by the author(s)

DOI Link: http://doi.org/10.15580/GJAS.2018.2.020818020

http://gjournals.org/GJAS

\title{
Efficacy of Shear Butter (Butryospermum parkii) - Neem (Azadirachta indica) Leaf Meal Mixture on Performance and Carcass Characteristics, Immune Response and Blood Parameters in Broiler Chickens
}

\author{
Alagbe J. O., Soares D. M. and Eimoga M. M.
}

Poultry Section at Dan-malafia Farms, Ibadan

ARTICLE INFO

Article No.: 020818020

Type: Research

DOI: 10.15580/GJAS.2018.2.020818020

Submitted: 08/02/2018

Accepted: 20/02/2018

Published: $28 / 02 / 2018$

${ }^{\star}$ Corresponding Author

Alagbe J.O.

E-mail: demsonfarms@

yahoo.com

Keywords:

broilers, performance, carcass characteristics, heamatology,

immune response
ABSTRACT

An experiment was conducted to study the effect of Shear butter -neem leaf meal mixture (SBMM) as a dietary supplement on the growth performance viz., weight gain, feed intake and feed conversion ratio, carcass characteristics, immune response and some blood parameters of broiler chickens. One hundred and twenty one-day old commercial broiler chicks of mixed sex (Arbo acre) were reared in a deep litter poultry house and divided into four (4) groups of thirty (30) birds each. The groups were assigned to four diets containing 0, 2.0, 4.0 and 6.0\% SBMM. Feed and water were provided ad libitum throughout the experimental period which lasted for $\mathbf{4 2}$ days. The results showed that there was no significant $(P>0.05)$ difference in body weight, weight gain and feed conversion ratio, feed cost per kilogram and immune response between treatment groups. The relative weights of the organs examined were not significantly $(P>0.05)$ different across dietary treatment. All the haematological parameters evaluated: Pack cell volume (PCV), Haemoglobin (Hb), White blood cell (WBC) were not significantly $(P>0.05)$ affected by the inclusion of SBMM. Nonsignificant influences were observed for total protein, albumin, and globulin, serum glutamic oxaloacetate transaminase (SGOT) and serum glutamic pyruvate transaminase (SGPT).

SBMM can be included up to $6.0 \%$ level in broiler chicken rations without any adverse effect on growth performance, carcass characteristics, immune response and blood profile of birds. 


\section{INTRODUCTION}

Shear tree, a member of the family Sapotaceae, is native to Africa. The tree is found in semi arid areas north of the humid forest zone and it can attain a height of 15 to22m and the trunk diameter varies from $0.5-1 \mathrm{~m}$ (Fernande et al, 2014), Bark conspicuously thick, corky, horizontally and longitudinally deeply fissured; protects older trees against bush fires. It has an extensive root system which is essential for its survival in the 5-7-month dry seasons of savannah climates.

According to FAO (1988) the leaves of shear butter are used as medicine to treat stomach ache in children and its fruit contains protein at $0.7-1.3 \mathrm{~g}$, carbohydrate $41.3 \mathrm{~g}-100 \mathrm{~g}$, iron $1.90-100 \mathrm{~g}$, calcium $34.4 \mathrm{mg}-100 \mathrm{~g}$ and ascorbic acid $196.1 \mathrm{mg}-100 \mathrm{~g}$ respectively. Shea butter contains vitamins $A$ and $E$, as well as catechins, plant antioxidants also found in green tea (Masters, 2004). Ayeh (1981) also reported that Shea butter is extracted from the nuts and are increasingly used for livestock and poultry feed, leaves and young sprouts serve as forage while small ruminants such as sheep and goats eat the sugary pulp of ripe fruit that have fallen to the ground. Studies have shown that the extract from the leaves are used to relieve headaches and eye bath (Taiwo, 2009; Abbiwo, 1990 and MaKeish. N. Dennie, 2012).

Shea butter possesses a significantly greater non saponifiable fraction than most other nut oils and fats, which lends the substance greater healing potential for the skin (Maranz et al, 2004).

Azadirachta indica belongs to the family meliaceae is a tropical evergreen tree widely distributed in Asia, Australia, Africa and other parts of the world (Girish and Shankara, 2008; Sombatsiri et al, 1995). A. indica performs several functions such as antibacterial, antifungal, antidiabetic, antitumor, anti-ulcer, antioxidant and used in the treatment of the parasitic infections (Subapriya and Nagini, 2005 ; Biswas et al, 2002). Pharmacological studies on the bark and leaves of the plants shows display effective antimicrobial activity (Chattopadhyay, 1996), the leaves have also been found to contain little amount of proteins and minerals (Ogbuewu et al, 2011).

Previous report have shown that Neem leaf meal exert a positive effect on growth performance of rabbits (Ugigwe et al, 2016) and blood profile of finisher broilers ( Jahanzeb et al, 2012; Obikaonu et al, 2014). Furthermore, scientific studies revealed that shea butter leaves contain B vitamins and sugar (Abidemi, 2009) and also perform multiple biological activities (Akihisa, 2010). Although extensive studies have been carried out on the neem and shear butter leaf meal in animals, yet there is a dearth of information on the combination of both leaf meals in broilers as the synesgistic combination could act as a natural detoxifier and colon cleanser thereby aiding nutrient absorption in the body of animals.
Therefore this study was carried out to investigate the growth performance, carcass characteristics, immune response and some blood parameters of broilers fed diets supplemented with Shear butter - neem leaf meal mixture.

\section{MATERIALS AND METHODS}

\section{Experimental site}

The experiment was carried out at the Poultry unit of Dan- malafia Farms, Oyo State, Nigeria.

\section{Animals and their management}

One -day old 120 broilers (Arbo acre) were obtained from a commercial hatchery in Ibadan. The chicks were reared in group and feed for one week before the start of the experiment on a commercial starter feed (adaptation period). At the end of the adaptation period, all chicks were weighed and assigned into four (4) dietary treatment groups; each group was further divided into three replicates each of ten (10) chicks in a completely randomized design (CRD). A deep litter poultry house was used; the house was cleaned and well disinfected before the commencement of the experiment. Vaccines were administered according to the prevailing vaccination schedule in the environment. Feed and water were offered ad-libitum. The light was continuous throughout the experimental period, the performance of the birds in terms of feed intake and mortality were recorded throughout the period of the experiment which lasted for 42 days.

\section{Preparation of experimental diet}

Fresh shea butter leaves were collected within the farm premises and washed. It was later spread on a concrete floor for 6 days to dry. The dried leaves from the strands are removed and grinded with a hammer mill and stored in a container.

Fresh leaves of Azadirachta indica (Neem) were harvested from matured neem plants within the farm premises and spread out evenly to dry under sunlight for 7 days untill the leaves became crispy to torch. The dried leaves were milled to produce neem leaf meal. The shear butter powder and neem leaf meal were mixed together in ratio of 1:1 respectively to form shear butterneem leaf meal mixture (SBMM). SBMM were mixed with other ingredients to form (4) experimental diets:

Treatment 1- $0 \%$ inclusion level

Treatment 2- Basal diet $+2.0 \%$ SBMM

Treatment 3- Basal diet $+4.0 \%$ SBBM

Treatment 4 - Basal diet $+6.0 \%$ SBBM 
All basal diet was formulated to meet the nutrient requirements of broiler chicks according to NRC (1994).

\section{Parameters measured}

The initial body weight was recorded at the beginning of the experiment and weekly thereafter, total feed and water consumption, mortality were recorded daily throughout the experimental period.

\section{Blood analysis}

At the $7^{\text {th }}$ week of the experiment, blood samples were collected from the brachial vein of four randomly selected birds per treatment. The blood samples were analyzed for some hematological and serum biochemical parameters; blood samples for hematology were collected into bottles containing Ethylene Diamine Tetra Acetate (EDTA). The hematological parameters such as Pack cell volume (PCV), Red blood cell (RBC), White blood cell (WBC), Haemoglobin concentration $(\mathrm{Hb})$ and absolute counts of neutrophils, lymphocytes, monocytes and eosinophils were computed according to the method of Jain (1986).

Blood samples that were meant for serum biochemistry were collected into other bottles free from any anticoagulant. The serum total protein, Albumin and Globulin were computed according to (Doumas and Briggs, 1972), Glutamic oxaloacetate transaminase (SGOT), Glutamic phosphatase transaminase (SGPT) was determined according to Scott (1965).

\section{Carcass Evaluation}

At the end of the seventh week, five birds were randomly selected per treatment; they were fasted overnight and given only water, weighed and slaughtered. After evisceration, the organs were removed and weighed. The carcass weight, dress weight, weight of the visceral organs and other parts of the birds were also recorded.

\section{Immune Parameters}

Birds were orally vaccinated against against Gumboro virus (on the $11^{\text {th }}$ and $20^{\text {th }}$ days) and Newcastle disease (on the $9^{\text {th }}$ and $16^{\text {th }}$ days). Four (4) birds were randomly selected per replicate to access the antibody response to Newcastle and gumboro virus on the $28^{\text {th }}$ and $42^{\text {nd }}$ day of the experiment. Blood samples were collected from the branchial vein of the vaccinated birds and sent to the laboratory for further analysis. Antibody titers against Newcastle and Gumboro viruses were measured using Hemaaglutination Inhibition Test.

\section{Cost Benefit Analysis}

Cost analysis of each diet fed to the experimental birds was calculated. The cost of per $\mathrm{kg}$ of ingredient was used to multiply the total feed intake per bird to obtain the total cost of feed consumed during the experimental period.

\section{Chemical Analysis}

The proximate components of Tridax procumbens meal (Powder) and samples of the four experimental diets were determined by method of A.O.A.C (1990).

\section{Statistical Analysis}

All data collected were subjected to one way Analysis of variance (ANOVA) by Steel and Torrie (1980). Significant means separated by Duncan multiple range test (Duncan, 1955).

Table 1: Proximate Composition of Shear butter leaf meal

\begin{tabular}{lc}
\hline Parameter & Dry matter (\%) \\
\hline Crude protein & 12.54 \\
Ether extracts & 5.40 \\
Total ash & 6.96 \\
Crude fibre & 10.40 \\
Nitrogen free extract (NFE) & 64.74 \\
\hline
\end{tabular}

Table 2: Proximate Composition of Neem leaf meal

\begin{tabular}{lc}
\hline Parameter & Dry matter $(\%)$ \\
\hline Crude protein & 17.84 \\
Ether extracts & 2.40 \\
Total ash & 5.06 \\
Crude fibre & 15.70 \\
NFE & 59.00 \\
\hline
\end{tabular}

NFE: Nitrogen Free Extracts 
Table 3: Composition of experimental (Broiler starter) diets (\%)

\begin{tabular}{lcccc}
\hline Ingredients & \multicolumn{3}{c}{ Diets } \\
\hline & 1 & 2 & 3 & 4 \\
Maize & 51.95 & 51.85 & 51.75 & 51.65 \\
Soy bean meal & 26.00 & 25.00 & 26.00 & 25.00 \\
Groundnut cake & 16.00 & 17.00 & 16.00 & 17.00 \\
Bone meal & 3.00 & 3.00 & 3.00 & 3.00 \\
Limestone & 2.00 & 2.00 & 2.00 & 2.00 \\
Lysine & 0.25 & 0.25 & 0.25 & 0.25 \\
Methionine & 0.25 & 0.25 & 0.25 & 0.25 \\
Premix & 0.25 & 0.25 & 0.25 & 0.25 \\
Salt & 0.30 & 0.25 & 0.25 & 0.25 \\
SBMM & 0.00 & 2.00 & 4.00 & 100.0 \\
\hline & 100 & 100.0 & 100 & 23.09 \\
Determined Analysis & & & 4.02 \\
Crude protein (\%) & 23.19 & 23.10 & 23.17 & 3.92 \\
Crude Fibre (\%) & 4.00 & 4.01 & 4.00 & 6.71 \\
Ether extract (\%) & 3.90 & 3.91 & 3.90 & 3101.05 \\
Ash (\%) & 6.67 & 6.70 & 6.66 & 3130.52 \\
Energy (Kcal/kg) & 3140.64 & 3138.41 & & \\
\hline
\end{tabular}

*Premix supplied per kg diet :- Vit A, 12,000 I.U; Vit E, 5mg; Vit D3, 3000I.U, Vit K, 3mg; Vit B2, 5.5mg; Niacin, 25mg ; Vit B12, 16mg ; Choline chloride, 120mg ; Mn, 5.2mg ; Zn, 25mg ; Cu, 2.6g ; Folic acid, 2mg ; Fe, $5 \mathrm{~g}$; Pantothenic acid, $10 \mathrm{mg}$; Biotin, $30.5 \mathrm{~g}$; Antioxidant, 56mg

Table 4: Composition of experimental (Broiler finisher) diets (\%)

\begin{tabular}{lcccc}
\hline Ingredients & \multicolumn{3}{c}{ Diets } & 4 \\
\hline & 1 & 2 & 3 & 59.70 \\
Maize & 60.00 & 59.90 & 59.80 & 5.00 \\
Wheat offal & 5.00 & 5.00 & 5.00 & 17.00 \\
Soya meal & 17.00 & 17.00 & 17.00 & 12.00 \\
Groundnut cake & 12.00 & 12.00 & 12.00 & 3.00 \\
Bone meal & 3.00 & 3.00 & 3.00 & 1.50 \\
Limestone & 1.50 & 1.50 & 1.50 & 0.25 \\
Lysine & 0.25 & 0.25 & 0.25 & 0.25 \\
Methionine & 0.25 & 0.25 & 0.25 & 0.25 \\
Premix & 0.25 & 0.25 & 0.25 & 0.30 \\
Salt & 0.30 & 0.30 & 0.30 & 6.00 \\
SBMM & 0.00 & 2.00 & 4.00 & 100.0 \\
\hline & 100.0 & 100.0 & 100.0 & 20.09 \\
Determined Analysis & & & 20.17 & 4.12 \\
Crude protein (\%) & 20.19 & 20.10 & 4.09 & 3.22 \\
Crude Fibre (\%) & 4.10 & 4.11 & 3.20 & 6.71 \\
Ether extract (\%) & 3.20 & 3.21 & 6.66 & 2991.05 \\
Ash (\%) & 6.67 & 6.70 & 2990.52 & \\
Energy (Kcal/kg) & 2990.64 & 2990.41 & &
\end{tabular}

*Premix supplied per kg diet :- Vit A, 8,000 I.U; Vit E, 5mg; Vit D3, 3000I.U, Vit K, 3mg; Vit B2, 5.5mg; Niacin, 25mg ; Vit B12, 16mg ; Choline chloride, 120mg ; Mn, 5.2mg ; Zn, 25mg ; Cu, 2.6g ; Folic acid, 2mg ; Fe, $5 \mathrm{~g}$; Pantothenic acid, $10 \mathrm{mg}$; Biotin, $30.5 \mathrm{~g}$; Antioxidant, 56mg. 
Table 5: Effect of different levels of SBMM on the performance of broilers

\begin{tabular}{lccccc}
\hline Parameters & \multicolumn{5}{c}{ Diets } \\
\hline Performance (g) & 1 & 2 & 3 & 4 & SEM \\
Number of birds & 30.0 & 30.0 & 30.0 & 30.0 & - \\
Initial live weight (g/bird) & 104.0 & 103.0 & 102.7 & 104.2 & 10.20 \\
Final live weight (g/bird) & 2089.3 & 2090.2 & 2004.1 & 2006.1 & 38.01 \\
Total feed intake (g/bird) & 3180.7 & 3105.0 & 3130.8 & 3102.4 & 65.12 \\
Total weight gain (g/bird) & 1985.3 & 1987.2 & 1901.4 & 1901.9 & 11.31 \\
Feed conversion ratio (FCR) & 1.52 & 1.49 & 1.56 & 1.55 & 0.26 \\
Daily water intake (lit/day) & 25.0 & 25.2 & 25.6 & 25.8 & 1.06 \\
Mortality & $2 / 30$ & $1 / 30$ & 0.00 & $1 / 30$ & 0.06 \\
Cost-benefit analysis & & & 140.1 & 140.1 & 7.90 \\
Feed cost /kg & 140.0 & 140.0 & & &
\end{tabular}

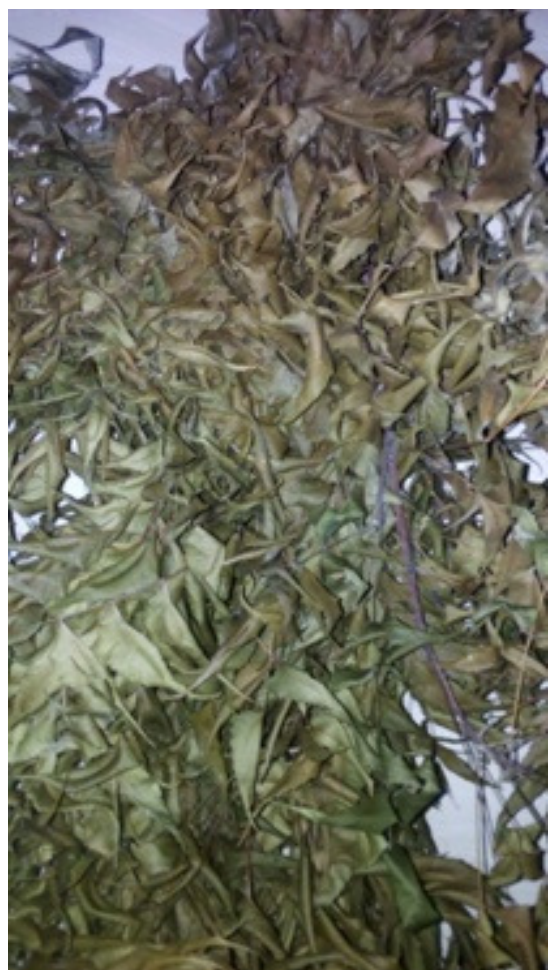

Figure 1. Dried Neem leaf

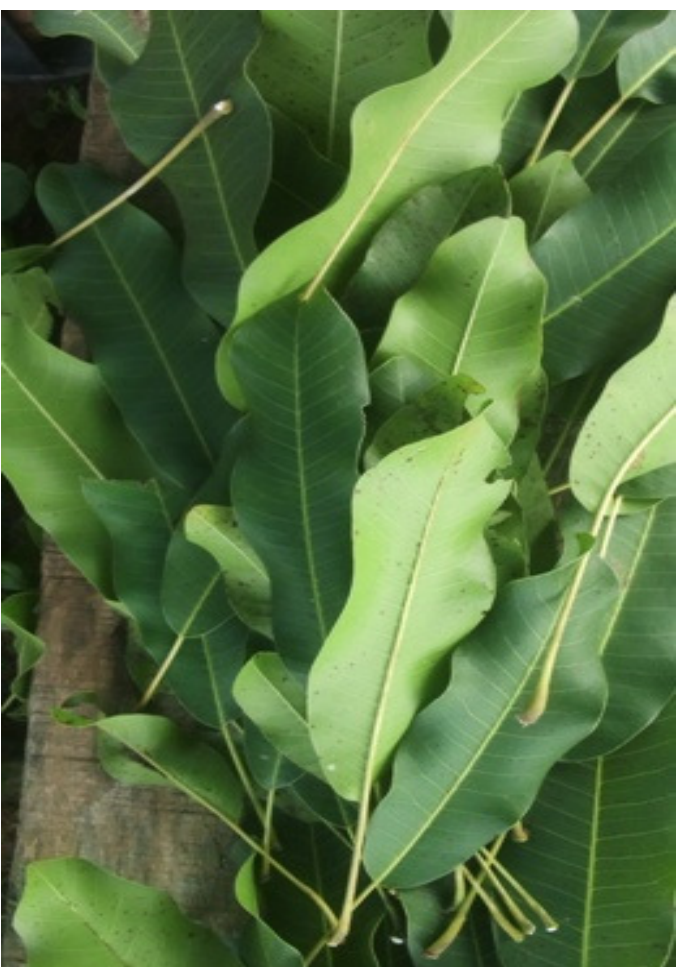

Figure 2. Freshly harvested Shear butter leaf 


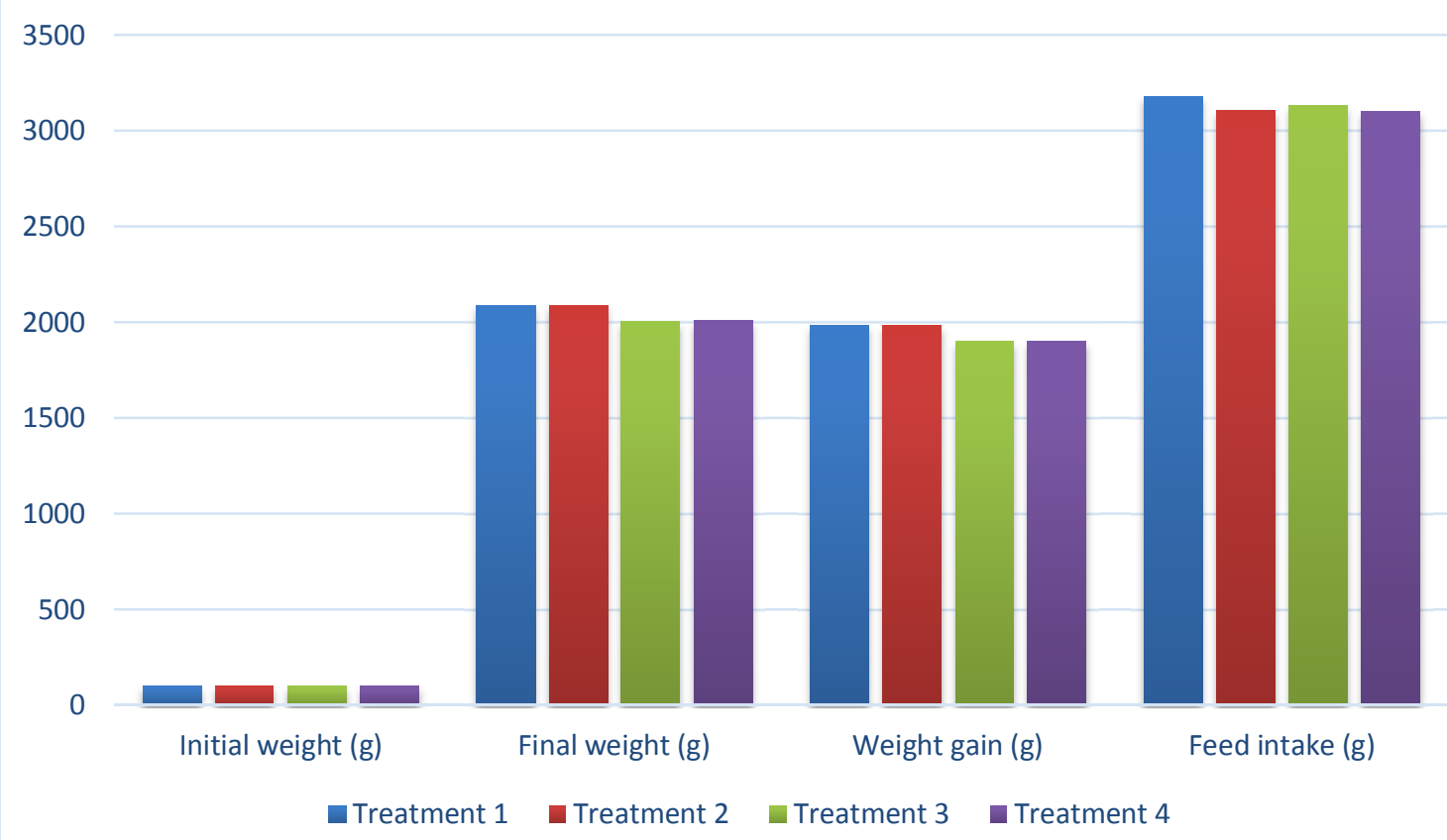

Figure 3. The effect of dietary inclusion of shear butter -neem leaf mixture (SBMM) on the initial weight, final weight and feed intake of broilers chicks for $\mathbf{4 2}$ days

Table 6: Effect of feeding different levels of SBMM on haematological parameters of broilers

\begin{tabular}{lccccc}
\hline Parameters & \multicolumn{5}{c}{ Treatments } \\
\hline & 1 & 2 & 3 & 4 & SEM \\
Pack cell volume (\%) & 38.40 & 38.19 & 38.09 & 39.71 & 0.54 \\
Haemoglobin (g/dl) & 15.60 & 15.71 & 15.69 & 15.09 & 0.20 \\
Red blood cell (10)6mm & 2.00 & 2.03 & 2.06 & 2.10 & 0.04 \\
White blood cell (10)6mm & 12.07 & 11.88 & 11.68 & 11.41 & 1.27 \\
Neutrophil (\%) & 70.11 & 70.81 & 70.60 & 70.34 & 1.01 \\
Monocytes (\%) & 3.11 & 3.10 & 3.01 & 3.09 & 0.02 \\
Lymphocytes (\%) & 49.97 & 49.59 & 49.51 & 49.57 & 1.06 \\
Eosinophils (\%) & 4.11 & 4.01 & 4.03 & 4.08 & 0.49 \\
\hline
\end{tabular}

Table 7: Serum biochemical indices of broilers fed different levels of SSMM

\begin{tabular}{lccccc}
\hline \multicolumn{5}{c}{ Treatments } \\
\hline Parameters & 1 & 2 & 3 & 4 & SEM \\
\hline Albumin (g/dl) & 1.50 & 1.50 & 1.55 & 1.49 & 0.61 \\
Globulin (g/dl) & 1.20 & 1.10 & 1.20 & 1.20 & 0.12 \\
Total protein (g/dl) & 2.70 & 2.60 & 2.75 & 2.69 & 0.15 \\
SGPT (iu/l) & 18.78 & 18.51 & 18.02 & 18.61 & 0.14 \\
SGOT (iu/l) & 91.06 & 91.89 & 91.01 & 91.66 & 4.06 \\
\hline
\end{tabular}

SGPT: Serum glutamic pyruvate transaminase

SGOT: Serum glutamic oxaloacetate transaminase 
Table 8: Carcass characteristics and relative organ weights of broilers fed SSMM

\begin{tabular}{lccccc}
\hline & \multicolumn{5}{c}{ Treatments } \\
\hline Parameters & 1 & 2 & 3 & 4 & SEM \\
Final dress weight $(\mathrm{g})$ & 1539.3 & 1540.2 & 1454.1 & 1456.1 & 21.07 \\
Dressing percentage & 73.68 & 73.69 & 72.56 & 72.58 & 9.01 \\
Head & 6.10 & 6.21 & 6.37 & 6.32 & 0.05 \\
Neck & 4.11 & 4.13 & 4.23 & 4.33 & 0.41 \\
Thigh & 10.03 & 10.15 & 10.24 & 10.20 & 0.51 \\
Shanks & 7.20 & 7.22 & 7.24 & 7.22 & 1.10 \\
Liver & 2.52 & 2.37 & 2.56 & 2.51 & 0.11 \\
Pancreas & 0.46 & 0.41 & 0.48 & 0.49 & 0.15 \\
Gizzard & 3.07 & 3.01 & 3.10 & 3.11 & 0.11 \\
Proventriculus & 0.47 & 0.43 & 0.41 & 0.49 & 0.12 \\
Intestine (cm) & 154.2 & 155.9 & 156.0 & 158.9 & 5.67 \\
\hline
\end{tabular}

Table 9. Effect of different level of SSBM on the immune response of broilers

\begin{tabular}{|c|c|c|c|c|c|}
\hline \multirow[t]{2}{*}{ Parameters } & \multicolumn{4}{|c|}{ Treatments } & \multirow[b]{2}{*}{ SEM } \\
\hline & 1 & 2 & 3 & 4 & \\
\hline At day 28 & & & & & \\
\hline Newcastle (ND) log2 & 2.60 & 2.54 & 2.49 & 2.51 & 0.09 \\
\hline Gumboro (IBD) log 2 & 3.11 & 3.17 & 3.06 & 3.13 & 1.10 \\
\hline At day 45 & & & & & \\
\hline Newcastle (ND) log 2 & 5.17 & 5.07 & 5.21 & 5.11 & 0.32 \\
\hline Gumboro (IBD) log2 & 4.40 & 4.31 & 4.22 & 4.27 & 0.17 \\
\hline
\end{tabular}

\section{RESULTS}

Table 1 and 2 shows the proximate analysis of Shear butter leaf meal and Neem leaf meal respectively. The values obtained for shear butter leaf meal are $10.54 \%$, $5.40 \%, 6.96 \%, 10.40 \%$ and $66.74 \%$ for crude protein, ether extract, total ash, crude fibre and nitrogen free extract respectively while those of neem leaf are $17.84 \%, 2.40 \%, 5.06 \%, 15.70 \%$ and $59.00 \%$ for crude protein, ether extract, total ash, crude fibre and nitrogen free extract. Table 3 and 4 reveals the proximate composition of experimental diets. The proximate components reveal that the crude protein of broiler starter mash ranges between $23.09-23.19 \%$ while those of broiler finisher are between 20.09-20.10 all values obtain fall within the range recommended by NRC (1994) for birds.

The growth performances as influenced by the treatments are presented in Table 5 . The average final weight ranges between 2004.1-2089.3g. There was no significant difference $(P>0.05)$ among the treatments in terms of the live weight. The average feed intake values obtained are 3180.7, 3105.0, 3130.8 and 3102.4 (g/bird) for treatments $1,2,3$ and 4 respectively while those of the total weight gain are 1985.3, 1987.2, 1901.4 and 1901.9 (g/bird) for diets 1, 2, 3 and 4. The feed conversion ratio (FCR) values obtained are 1.52, 1.49, 1.56 and 1.55 for treatments $1,2,3$ and 4 respectively while those of daily water intake are 25.0, 25.2, 25.6 and
25.8 liters/day for treatments $1,2,3$ and 4 . The average feed intake, feed intake, total weight gain, feed conversion ratio and daily water intake were not significantly affected $(P>0.05)$ by the dietary inclusion of SBMM, the daily water consumption gradually increased from treatment 1 to 4 . Table 6 reveals the values of the hematological parameters investigated; the pack cell volume (PCV) values obtained are 38.40, 38.19, 38.09 and $39.71 \%$ for treatments $1,2,3$ and 4 respectively while those of hemoglobin $(\mathrm{Hb})$ values obtained are $15.60,15.71,15.69$ and $15.09 \mathrm{~g} / \mathrm{dl}$ for treatments $1,2,3$ and 4. The Red blood cell (RBC) are 2.00, 2.03, 2.06 and $2.10(10) 6 \mathrm{~mm}$ for diets $1,2,3$ and 4 respectively while those of White blood cell (WBC) are 12.07, 11.88, 11.68 and 11.41 (10)6mm for diets 1, 2, 3 and 4 respectively. The pack cell volume (PCV), haemoglobin $(\mathrm{Hb})$, red blood cell (RBC) were not significantly ( $P>0.05)$ different among the dietary treatments. The neutrophil values obtained are $70.11,70.81,70.60$ and $70.34 \%$ for treatments $1,2,3$ and 4 respectively while those of monocytes values are 3.11, 3.10, 3.01 and 3.09 $\%$ for treatments 1, 2, 3 and 4 . The lymphocytes values obtained are $49.97,49.59,49.51$ and $49.57 \%$ for treatments $1,2,3$ and 4 respectively while those of eosinophils values are $4.11,4.01,4.03$ and $4.08 \%$ for diets 1, 2, 3 and 4 respectively. White blood cell, neutrophils, lymphocytes, monocytes and eosinophils were not significantly $(P>0.05)$ influenced by different inclusion of SSMM. 
The serum biochemical parameters as influenced by the diets are presented on Table 7 . The albumin values obtained are 1.50, 1.50, 1.55 and 1.49 $\mathrm{g} / \mathrm{dl}$ for treatments $1,2,3$ and 4 respectively while those of globulin values are $1.20,1.10,1.20$ and $1.20 \mathrm{~g} / \mathrm{dl}$ for treatments $1,2,3$ and 4 . The total protein values obtained are 2.70, 2.60, 2.75 and $2.69 \mathrm{~g} / \mathrm{dl}$ for treatments 1, 2, 3 and 4 respectively. Albumin, globulin and total protein were not significantly $(P>0.05)$ influenced by different inclusion of SSMM. The SGPT values obtained are 18.78, 18.51, 18.02 and $18.61 \mathrm{iu} / \mathrm{l}$ for treatments $1,2,3$ and 4 while those of SGOT are 91.06, 91.89, 91.01 and $91.66 \mathrm{iu} / \mathrm{l}$ for diets 1, 2, 3 and 4 respectively.

The carcass characteristics and the relative organ weights of broilers fed different levels SSMM is presented in Table 8 . The relative weights of the head, neck, thigh, shanks, liver, pancreas, gizzard, proventriculus and intestine fed SSMM were not significantly $(P>0.05)$ different from the control diets. The dressing percentage values obtained are $73.68 \%$, $73.69 \%, 72.56 \%$ and $72.58 \%$ for treatments $1,2,3$ and 4 respectively.

The immune response parameters as influenced by the diet are presented in Table 9 . On the $28^{\text {th }}$ day Newcastle disease $(\log 2)$ titers obtained are 2.60, 2.54, 2.49 and 2.51 for treatments $1,2,3$ and 4 respectively while those of Gumboro $(\log 2)$ are 3.11, 3.17, 3.06 and 3.13 for treatments $1,2,3$ and 4 respectively. The values obtained for N.D titers on the $45^{\text {th }}$ day are 5.17 , $5.07,5.21$ and $5.11(\log 2)$ for treatments $1,2,3$ and 4 respectively while those of IBD are 4.40, 4.31, 4.22 and 4.27 for diets $1,2,3$ and 4 respectively. The values of the antibody titer production for both N.D and IBD were not significantly $(P>0.05)$ influenced by different inclusion of SSMM.

\section{DISCUSSION}

The proximate values of Shear butter and Neem leaf meal agree with the findings of Abidemi et al (2009) and Obikaonu et al (2014) but contrary to the reports of Oforjindu (2006) and Esonu et al (2006). The crude protein values in treatments 1 to 4 did not significantly $(P>0.05)$ affect the final weight of the birds, which implies that the protein level is enough to support the growth of the animals. According to NRC (1994) feeds containing $22-23 \%$ and $20-21 \%$ crude protein have been reported to be suitable for broilers at starter and finishing phase. The highest feed intake was recorded in broilers fed diet 1, followed by diet 3,2 and 4 respectively across the experimental period (7 weeks), however, there was no significant $(P>0.05)$ differences in the final live weight of the birds. Broilers in treatment 4 had the highest weight gain followed by diet 3,1 and 2 respectively, the result obtained agrees with the reports of Naderi et al (2014) and Imasuen et al (2014) when broilers were fed diets supplemented with turmeric and pumpkin leaf respectively. Birds fed diet 1 had the highest mortality of
2, followed by diets 2 and 4 respectively. No mortality was recorded in birds fed treatment 3 , this report affirm the earlier observation of Tollba and Hassan (2003) when broilers were fed diets supplemented with Nigella sativa or garlic under high temperature conditions.

The non-significant $(P>0.05)$ differences in the values obtained for daily water intake and feed cost per kilogram across the treatment groups agrees with the findings of Ojabo et al (2012) when rabbits were fed sweet orange peels, the water intake is a clear indication that the intestinal walls of the birds are well protected.

Haematological studies represent a useful process in the diagnosis of diseases as well as investigation of the extent of damage to blood (Isaac et al, 2013); animals with good blood composition reflect good performance (Bamishaiye et al, 2009). Parameters like $\mathrm{Hb}$ value, WBC, RBC among others are used in routine screening for the health and physiological status of livestock (Aro et al, 2013).

There was no significant $(P>0.05)$ differences in the haematological parameters investigated, it shows that the animals were well nourished. The experimental diet contains enough protein, energy and minerals, which are necessary for the normal functioning of the animal's body. The values for all the parameters fall within the normal range values established for birds by Ibrahim Albokhadaim (2012); Obikaonu et al (2014). According to Ologun and Ikeobi (2006) RBC serves as a carrier of haemoglobin, transport of oxygen and carbon dioxide in the body (Isaac et al, 2013), PCV is involved in the transport of oxygen and absorbed nutrients (Maton et al, 1993). Hemoglobin plays a vital role in oxygen transportation to tissues of animals (Soetan et al, 2013). Adeyinka and Bello (2013) reported that WBC and its differentials fight infections and produce antibodies to protect the body.

The total protein, albumin and globulin of the broilers used in this experiment were not affected $(P>0.05)$ by the inclusion of SSMM. Albumin content in the blood are easily influenced by protein shortage, the results obtained is an indication that the experimental diets contained enough protein to support the normal protein reserves across the group. The values for all the parameters fall within the normal range values established for birds by Ibrahim Albokhadaim (2012).

The values obtained for SGPT and SGOT were not significantly $(P>0.05)$ different among the treatment. According to lyayi (1994) SGPT and SGOT values usually respond to the presence of toxic substances in the diet. The result obtained is contrary to the report of Alagbe, J. O (2016) on the effect of heavy metals contamination on the performance and blood profile of broiler chicks.

SSMM inclusion did not significantly $(P>0.05)$ affect the carcass and organ weight of the birds, this results obtained in this experiment is in agreement with the reports of Bolu et al (2009) when dried pawpaw seeds were fed to broiler chickens. According to Madhusadha et al (1986) antinutrients are causes of internal organs enlargement in birds, the significant 
differences in the carcass characteristics could also be attributed to the quality of diet in each treatment.

The values of the antibody titer production for both ND and IBD were not significantly $(P>0.05)$ affected by the different supplementation of SSMM, this report agrees with the findings of Nouzarian et al (2011) on the effect of turmeric on the immune response, performance and carcass traits of broiler chickens.

\section{CONCLUSION}

The growth, carcass characteristics, blood profile and immune parameters measured showed significant no differences. It could therefore be concluded that SSMM could be efficiently utilized and tolerated by broiler chickens up to $3 \%$ inclusion level without any negative effect on the performance and health status of broiler chickens.

\section{REFERENCES}

1. Adeyinka, J.N and Bello, H.O (2013).Serum biochemical parameters in clinically healthy dogs in Ibadan. Tropical Veterinarian 16(3-4), 123-120.

2. Abidemi, Taiwo. A., Oyedepo, J. Adebayo., Oluwadare, Idowu and Agbotoba, M. O (2009). Nutrient content and anti-nutritional factor of shea butter leaves. African Jou'l of Biotech, Vol 8(21) pp 5888-5890, 2 Nov, 2009.

3. Alagbe, J. O (2016). Effect of heavy metals contamination on the performance and blood profile of broiler chicks fed corn-soya meal diet. Int'l Journal of Advanced Biological Research, I.J.A.B.R, Vol6(4)2016: 538-542.

4. Akihisa, T., Kojima, N., Katoh, N., Ichimura, Y., Suzuki, H., Fukatsu, M., Maranz, Z and Masters, E.T (2010)Triterperne alcohol and fatty acid composition of shea nuts from Seven African Countries. Jour'l of Oleo Sci. 59:351-360.

5. Aro, S. O., Ogunwale, F. F and Falade, O.A (2013). Blood viscosity of finisher cockerel fed dietary inclusions of fermented tuber wastes. Proc. of the $18^{\text {th }}$ Annual Conf. of Ani. Sci. Assoc. of Nig. 74-77.

6. A.O.A.C (1990). Association of Official Analytical Chemists. Official Methods of Analysis $15^{\text {th }}$ Edition Washington, D.C Pp69-77.

7. Ayeh (1981). The study of shea butter: the extraction of Shea butter. Int'l Jou'l of Pham. 30:117-123.

8. Bamishaiye, E O (2009). Haematological parameters of albino rats fed on tiger nuts (Cyperus esculentus) tuber oil meat based diet. The internet Journal of Nutrition and Wellness; 10(1).

9. Biswas, K. I., Chattopadhyay, R., Banejee, K and U. Bandyspadhyay (2002). Biological activities and medicinal properties of Neem. Curr. Sci. 82(11): 1336-1345.

10. Bolu, S.A.O., Sola-Ojo, F.E., Olorunsanya, O.A and Idris, K (2009) Effect of graded levels of Pawpaw
Seed on the Performance, haematology and Serum biochemistry and Carcass evaluation of Broiler chickens. Asian Network for Scientific Information, International Journal of Poultry Science 8(9):905909.

11. Chattopadhyay, R. R (1996). Possible mechanism of anti-hyperglycemic effects of Neem leaf extracts. Part IV. General Pharmacology, 27: 431-434.

12. Doumas, B.T and Briggs, H.G (1972) Serum Albumen Bromocresol Green Binding Standard Methods. Clinical Chemistry (7) 175-179.

13. Esonu, B. O., Ihekwumere, F. C., Emenalom, O. O., Uchegbu, M. C and Etuk, E . B (2002) Performance, nutrient utilization and organ characteristics of broilers fed Microdesmis puberula leaf meal. Livestock Research for Rural Development. Vol 14 (16) 146. www.cipar.org.collirrd/irrd14/6/eson. $146 \mathrm{httm}$.

14. FAO (1988). Traditional food plants. A resource book for promoting the exploiatation and consumption of food plants in semi -arid and subhumid lands of eastern Africa. Food and Nutrition Paper 42. FAO Rome.

15. Girish, D and Shankara, M (2008). Antibody activity and quantitative estimation of azadirachtin and nimbin in Azdirachta indica A. Juss grown in foothills of Nepal Afr. Jou'l Biotech. 8(13): 30843091.

16. Ibrahim Albokhadaim (2012). Haematological and some biochemical values of indigenous chickens in Al-Ahsa, Saudi Arabia during summer season. Asian Journal of Poultry Sciences. 6(4):138-145,2012.

17. Imasuen, J. A., Nwokoro, S. O and U. G. S, Osa (2014) Responses of broiler chicken fed varying level of dietary Telfaira occidentalis leaf as feed supplement. Asian Journal of Animal Sciences 8(2): 65-72, 2014.

18. Isaac, L. J., Abah, G., Akpan, B and Ekaette, I.U (2013) Haematological Properties of Different Breeds and Sexes of Rabbits (p.24-27). Proceedings of the $18^{\text {th }}$ Annual conference of Animal Association of Nigeria

19. Iyayi, E. A (1994). Supplemental effect of low and high cyanide cassava on the performance, nutrient digestibility and serum metabolites of growing pigs. J. Agric. Trop. Sub-trop 95:199-205.

20. Jahanzeb, Ansari., Sohail, Hassan Khan., Ahsan ul Haq and Muhammed, Yousaf (2012). Effect of the levels of dried neem leaf as phytogenic feed additive on growth performance and haemato-biochemical parameters in broiler chicks. Jou'l of Applied Animal Research, Vol 40, No 4, Dec 2012, 336-345.

21. Jain, N.C (1986) Schalms veterinary hematology $4^{\text {th }}$ edition Lea and Febiger, Philadelphia.

22. Obikaonu, H.O., V. M, Mmremikwu., V. U, Odoemena., I. C, Okoli and A.B.I, Udedibie (2014) Haematological and Serum Biochemical Indices of Broiler Finisher Fed Neem Leaf Meal. Int'l Journal of Agric and Rural Development. SAAT FUTO 2014, Vol 17(1) 1641-1647, 2014. 
23. Oforjindu, $O$ (2006) .The toxicity graded levels of Neem leaf meal. B. Agric Tech Project Report, FUTO, 56-57.

24. Ogbuewu, I. P., Odoemenam, V. U., Obikaonu, H. O., Opara, M. N., Emenalom, O. O., Uchegbu, M. C., Okoli, I. C ., Esonu, B. O and Iloje, M. U (2011). The growing importance of Neem in Agriculture, Industry, Medicine and Environment: A Review". Research Jou'l of Medicinal Plants 5(3), 230-245.

25. Ojabo, L.D, Adenkola, A.Y and Odaudu, G.I (2012) The effect of dried Sweet orange fruit peel meal on the growth performance and haematology of rabbits. Medwell Journals Veterinary Research 5(2): 26-30, 2012.

26. Ologun and Ikeobi (2006). Hematological and Serological Characteristics of Cockerels Fed Different Levels of Tiger nut seed meal. International Journal of Multidisciplinary Research and Review .Vol. 1 (1): 23-27.

27. Maton, P.B., Lemoullac, B.B., Aubcrio, D.O (1993) Changes in rat plasma apolioprotein and lipoprotein during moderate protein deficiency. Potential use in the assessment of nutritional status. Journal of nutrition, 121(5) 653-662.

28. Madhusadhan, K.T., Ranesh, H.P., Ogawa, T, Sasoka, K and Singh, N (1986). Detoxification of commercial linseed meal for use in broiler ration. Poultry Science, 65:164-171.

29. Maranz, S., Kpikpi, W., Wiesman, Z., De Saint Sauveur, A and Chapagain, B (2004). Nutritional values and Indigenous preferences for shea fruits in African agroforestry parklands. Econ Bot 58: 588600.

30. MaKeish N Dennie (2012). Medicinal Benefits of Shea Nut Tree. Biology Student Research. Paper 1. http://digitalscholarship.tnstate.edu/biology students 11.

31. Masters, E.T., Yidana, J.A and Lovett, P. N (2004). Reinforcing sound management through trade: Shea tree products in Africa. Unasylva. 55:46-52.

32. Naderi, M., Akbari, M. R., Asadi-Khoshoei, E., Khaksar, K and Khajali, F (2014). Effect of Dietary inclusion of Turmeric and Cinnamon Powders on Performance, Organs relative weight and some immune parameters of broiler chicken. Poultry Science Journal 2(2): 153-163.

33. Nouzarian, R., Tabeidian, S. A., Toghyani, M ., Ghalamkari, G and Toghyani, M (2011) Effect of Turmenric powder on performance, carcass traits, humoral immune response and serum metabolites in broiler chickens. Journal of Animal and Feed Sciences 20, 2011, 389-400.

34. NRC, National Research Council (1994) Nutrient Requirement for Poultry (9 $9^{\text {th }}$ rev ed) National Academy Press. Washington D. C, USA.

35. Scott, H.M (1965) Measurement of Albino Acid content of fish meal protein by chick growth assay, P.Sc., pp: 395-65.

36. Soetan, K.O., Akinrinde, A.S and AJibade T.O (2013). Preliminary studies on the haematological parameters of cockerels fed raw and processed guinea corn (Sorghum bicolor) Pg 42-52. Proceedings of $38^{\text {th }}$ Annual Conference of Nigerian Society of Animal Production.

37. Sombatsiri, K., Ermel, K and Schmutterer, H (1995). Other meliaceous plants containing ingredients for integrated pest management and further purpose. In: Schumutter, $\mathrm{H}(\mathrm{Ed}$.$) , the neem tree Azadirachta$ indica A. Juss and other meliaceous plants. $\mathrm{VCH}$, Germany, pp. 585-597.

38. Steel, R. G.D and Torrie, J.H (1980). Principles and procedures of sataistics. A biometrical approach, $2^{\text {nd }}$ edn McGraw-Hill Book Coy. NY. USA.

39. Subapriya, M and Nagini, O (2005). Antibacterial effect of Neem Oil on multidrug resistant bacteria isolated from human infections. Int'l Jou'l of Biological \& Medical Research, 4(4), 3544-3546.

40. Tollba, A. A and Hassan, M. S (2003) Using some natural feed additives to improve physiological and productive performance of broiler chicks under high temperature conditions. Black cumin (Nigella sativa) or Garlic powder. Poult. Sci. 23:327-340.

41. Unigwe, C. R., Balogun, F. A., Okorafor, U. P., Abonyi, F. O and Olona, J. F (2016). World Scientific News WSN 55(2016) 51-62. Available online at www.worldscientificnews.com 